\title{
KARAKTERISTIK INTERTWINING DALAM PENDEKATAN MATEMATIKA REALISTIK DI SEKOLAH DASAR
}

\author{
Hongki Julie \\ Program Studi Pendidikan Matematika, FKIP, Universitas Sanata Dharma, Yogyakarta \\ Kampus III Universitas Sanata Dharma, Paingan, Maguwoharjo, Depok, Sleman \\ E-mail: hongkijulie@yahoo.co.id.
}

\begin{abstract}
The aim of this study is to describe intertwining characteristic or knowledge relations in realistic mathematics approach and what are teachers need to do in the mathematics learning process until the intertwining characteristic arise. The research development is applied in three phase. The data collection was done by observation and video recording during the learning process. Research objects are sixth-grade Elementary School students in Yogyakarta. The results of this study showed that the intertwining characteristic in realistic mathematics approach emphasizes a series of learning as a combination of learning series that must be used in problemsolving. Things that teachers should do is to create a series of problems that are explored and solved by students so mathematics formal language is well achieved.

Keywords: intertwining characteristic, realistic mathematics approach, elementary school

Abstrak: Penelitian ini bertujuan untuk mendeskripsikan karakteristik intertwining atau jalinan pengetahuan dalam pendekatan matematika realistik dan hal-hal yang perlu dilakukan guru dalam proses pembelajaran matematika hingga karakteristik intertwining muncul. Penelitian ini berjenis penelitian pengembangan yang dibagi dalam tiga fase. Pengumpulan data dilakukan dengan pengamatan dan perekaman video selama proses pembelajaran berlangsung. Subjek penelitian siswa kelas 6 SD di Yogyakarta. Hasil yang didapatkan: karakteristik intertwining dalam pendekatan matematika realistik menekanan rangkaian pembelajaran sebagai suatu jalinan dari rangkaian pembelajaran yang harus dimanfaatkan dalam penyelesaian masalah. Halhal yang dilakukan guru untuk membentuk jalinan rangkaian pembelajaran adalah membuat rangkaian masalah yang dieksplorasi dan diselesaikan siswa hingga pengetahuan formal matematika dicapai dengan baik.
\end{abstract}

Kata kunci: karakteristik intertwining, pendekatan matematika realistik, sekolah dasar

Pada suatu kesempatan, peneliti mendapatkan kesempatan untuk mengamati seorang guru ketika mengajarkan kepada siswa bagaimana mengalikan dua bilangan dua digit dengan cara "bersusun ke bawah" di kelas 4 SD. Sebelum pertemuan tersebut, siswa sudah diajari oleh guru tentang bagaimana mengalikan bilangan dua digit dengan bilangan satu digit. Pada awal pertemuan, siswa diberi kesempatan oleh guru untuk mencoba menyelesaikan perkalian dua bilangan dua digit, tetapi siswa tidak dapat menyelesaikannya. Hal ini, terjadi karena siswa tidak mampu untuk mengembangkan pengetahuan yang sudah dimilikinya untuk menyelesaikan perkalian dua bilangan dua digit. Ketidakmampuan ini disebabkan karena dalam proses belajar siswa tidak diberikan ruang yang cukup oleh guru tersebut untuk mengonstruksi pengetahuannya sendiri dan membuat jalinan antara pengetahuan yang sudah dimilikinya dengan pengetahuan baru yang akan dibangunnya. 
Dalam proses pembelajaran yang dialami siswa di kelas tersebut, siswa hanya menerima, menyimpan, dan menggunakan informasi yang diberikan guru. Siswa tidak diberi kesempatan untuk menganalisis apa yang terkandung dalam informasi tersebut, dan untuk apa informasi yang diberikan kepadanya. Akibatnya, siswa berpikir bahwa konsep-konsep yang sudah dipahaminya tidak berhubungan sama sekali satu sama lain. Dampak lebih jauh, pengetahuan yang sudah dibentuk oleh siswa menjadi terkotak-kotak. Secara singkat, proses pembelajaran yang terjadi dalam kelas tersebut yaitu: (a) guru memberikan kesempatan kepada siswa untuk mencari hasil perkalian 25 dengan 16. Setelah ditunggu beberapa waktu, tidak ada siswa yang mampu melakukannya, (b) karena tidak ada siswa yang mampu menyelesaikan soal tersebut, maka guru mengajarkan kepada siswa tentang bagaimana mengalikan 25 dengan 16. (c) Guru memberikan latihan yang berisi soal-soal yang dapat diselesaikan dengan prosedur tersebut. (d) Guru membahas penyelesaian dari soal-soal latihan.

Dialog yang terjadi antara guru dengan semua siswa adalah

Guru: berapa $6 \times 5$ ?.

Siswa : tiga puluh.

Guru : ditulis berapa? ditulis berapa anakanak?

Siswa : nol

Guru : (guru menulis 0). Menyimpan berapa?

Siswa : tiga.

Guru : (guru menulis 3 di atas angka 2). Berapakah enam kali dua?

Siswa : dua belas.

Guru : Kemudian apa yang kalian lakukan selanjutnya? (sambil bertanya demikian, guru menunjuk angka 3 yang merupakan hasil penyimpanan langkah sebelumnya).

Siswa : lima belas.

Guru : mengapa bisa lima belas?

Siswa : ditambah.

Guru : (guru menuliskan angka 15 di depan 0). Berapakah satu kali lima?

Siswa : lima.

Guru : Angka lima ditulis di bawah nol atau lima?

Siswa : lima.

Guru : berapakah satu kali dua?

Siswa : dua.
Guru : (guru menjumlahkan 150 dengan 250, sehingga diperoleh 400).

Dari pengalaman observasi peneliti di kelas tersebut, maka ada suatu kesimpulan yang dapat dibuat oleh peneliti, yaitu bahwa guru tidak memberikan kesempatan kepada siswa untuk mengonstruksi pengetahuannya sendiri dan membuat jalinan pengetahuan antara pengetahuan yang sudah dimiliki siswa dengan pengetahuan baru yang akan dibentuknya, sehingga meskipun siswa sudah punya pengetahuan untuk mengalikan bilangan dua digit dengan bilangan satu digit, siswa tidak mampu untuk mengembangkan pengetahuannya tersebut untuk menyelesaikan perkalian dua bilangan dua digit. Hal ini bertolak belakang dengan yang dikemukakan oleh In'am (2012) bahwa aktivitas yang dilakukan guru dalam pembelajaran hendaknya mampu mengembangkan strategi pembelajaran yang dapat mengantarkan murid untuk mengembangkan kemampuan dirinya menjadi pembelajar yang mandiri.

Pendidikan Matematika Realistik (PMR) pada awalnya dikembangkan oleh Hans Freudenthal di Belanda sekitar 40 tahun yang lalu. PMR masih dikembangkan di Belanda hingga saat ini oleh Freudenthal Institute. Filosofi dasar dari PMR adalah matematika sebagai aktivitas manusia, artinya matematika dalam pembelajaran dihubungkan dengan matematika sebagai suatu kegiatan manusia (Freudenthal, dalam Gravemeijer, 1994). Dengan kata lain, belajar matematika seharusnya dapat membuat siswa berpandangan bahwa matematika ada di dalam kegiatan manusia dan dapat digunakan dalam kehidupan nyata yang dijalani oleh manusia. Ada tiga prinsip utama di dalam PMR (Gravemeijer, 1994), yaitu: (1) penemuan kembali secara terbimbing (guided reinvention) dan matematisasi progresif (progressive mathematizing); (2) fenomenologi didaktis (didactical phenomenology); (3) mengembangkan modelmodel sendiri (self-developed models).

Treffers (dalam Gravemeijer, 1994) merekonstruksi suatu domain dari dalam pembelajaran matematika dengan pendekatan realistik. Treffers berhasil menyusun lima karakteristik dari matematisasi progresif yang ia padukan dengan prinsip penemuan kembali. Matematisasi progresif dapat dilekatkan dengan teori Van Hiele (dalam Gravemeijer, 1994) dan fenomenologi didaktis yang dikembangkan oleh Freudenthal (dalam Gravemeijer, 1994). 
Menurut Traffers (dalam Gravemeijer, 1994) proses matematisasi progresif dapat dikarakterisasi oleh lima karakter berikut.

Pertama, eksplorasi fenomenologis, dimulai dengan fenomena-fenomena, kemudian fenomenafenomena tersebut diorganisasikan. Mengapa siswa perlu diberikan kesempatan untuk melakukan eksplorasi terhadap suatu fenomena/masalah kontekstual. Menurut Widjaja (2013), masalah kontekstual berpotensi untuk melibatkan dan memotivasi siswa, tetapi juga akan menimbulkan tantangan bagi siswa. Menurut Widjaja (2013) pula, masalahmasalah kontekstual tidak dengan sendirinya akan menciptakan suatu pembelajaran yang bermakna bagi siswa, tetapi diperlukan guru yang mampu mengikutsertakan siswa dalam menginterpretasikan masalah agar siswa dapat mengeksplorasi ide-ide kunci yang bersifat matematis yang ada di dalam masalah kontekstual tersebut. Kedua, menggunakan instrumen-instrumen vertikal. Perhatian yang besar diberikan untuk model-model daripada memberikan kebenaran. Model-model situasi dan skema dimunculkan dari aktivitas penyelesaian masalah dan sesudah itu dapat membantu untuk menjembatani jurang antara level intuitif dan level sistematis.

Ketiga, kontribusi siswa, merupakan elemen konstruktif tampak dalam kontribusi yang banyak dalam pengajaran yang berasal dari konstruksikonstruksi yang dibuat oleh siswa dan hasil-hasil yang dicapai oleh siswa. Keempat, interaktivitas berkaitan dengan proses negosiasi, intervensi, diskusi, kerja sama, dan evaluasi yang eksplisit adalah elemen-elemen yang mendasar dalam suatu proses pembelajaran yang konstruktif, dimana dalam proses pembelajaran tersebut, metodemetode informal dari siswa dipergunakan sebagai pengungkit untuk mencapai level formal. Kelima, jalinan (intertwining), berkaitan dengan pendekatan holistik yang memasukkan aplikasi-aplikasi, menyatakan secara tidak langsung bahwa rangkaian pembelajaran tidak dapat diperlakukan sebagai sesuatu yang sungguh-sungguh terpisah, sebaliknya, rangkaian pembelajaran harus diperlakukan sebagai suatu jalinan yang terkait satu sama lain.

Garis besar proses pembelajaran yang menggunakan pendekatan matematika realistik yang dirancang oleh peneliti dan guru yang akan mencobakan desain pembelajaran adalah sebagai berikut: (a) siswa dibagi dalam lima kelompok yang terdiri dari 3 - 4 siswa; (b) siswa mendengarkan penjelasan guru tentang hal-hal apa saja yang perlu dilakukan pada saat melakukan percobaan dengan kacang hijau, alat dan bahan yang dibutuhkan tiap kelompok adalah sebagai berikut: sekotak kacang hijau, satu kotak kosong, satu gelas plastik, satu corong besar dan kecil, stopwatch, dan timbangan kue. Karena alat dan bahan yang tersedia hanya cukup untuk dua kelompok, maka siswa melakukan percobaan secara bergantian. Kelompok yang tidak melakukan percobaan, diminta untuk mengamati kelompok yang melakukan percobaan, (c) percobaan yang perlu dilakukan oleh tiap kelompok adalah sebagai berikut: tiap kelompok diminta untuk menuangkan sejumlah kacang hijau melalui corong kecil dan besar selama 10 detik dan 15 detik. Kemudian siswa diminta untuk menimbang dan mencatat berapa berat kacang hijau yang berhasil jatuh setelah dituangkan melalui corong tersebut. Tiap kelompok diminta mengulang kegiatan ini sebanyak 3 kali untuk tiap ukuran corong dan tiap waktu yang ditentukan. Tujuan dari percobaan ini adalah (1) siswa dapat mengalami fenomena yang dapat membangun pengertian debit, (2) siswa mengalami bagaimana proses mengumpulkan data, (3) siswa mengalami bagaimana mengolah dan menyajikan data dalam bentuk tabel dan diagram, (4) siswa dapat mengalami fenomena yang dapat membangun pengertian rata-rata dan menghitung rata-rata dari sekumpulan data, dan (5) siswa dapat membuat jalinan pengetahuan antara konsep debit dan rata-rata.

Langkah selanjutnya kegiatan pembelajaran selanjutnya yaitu: (d) sebelum siswa melakukan percobaan, satu siswa dari tiap kelompok diminta untuk mencoba mempergunakan stopwatch; (e) setelah tiap kelompok selesai mengadakan percobaan, guru meminta satu kelompok untuk menuliskan hasil percobaannya di papan tulis; (f) siswa diminta mengamati data hasil percobaan tersebut dan data hasil percobaan yang dihasilkan kelompoknya; (g) siswa diajak berdiskusi tentang bagaimana hasil yang diperoleh berdasarkan corong yang digunakan. Diskusi diarahkan agar siswa dapat memahami bahwa untuk corong yang lebih besar, maka dalam waktu penuangan yang sama, banyak kacang hijau yang dapat melewatinya akan lebih banyak dibandingkan jika menggunakan corong yang lebih kecil. Kaitkan percobaan ini dengan pengertian debit, dan bagaimana hubungan antara debit air yang dikeluarkan pipa yang memiliki 
diameter berbeda. (h) Siswa diminta menyimpulkan pemahamannya tentang pengertian debit, (i) setelah diskusi kelas selesai, tiap kelompok diberi tugas untuk menyajikan hasil percobaannya dalam bentuk grafik. Tiap kelompok dibebaskan untuk memilih grafik apa yang akan dibuat berdasarkan hasil percobaan tersebut, (j) setelah semua kelompok selesai membuat grafik, tiap kelompok diminta untuk me-nyajikan hasil diskusi kelompoknya dan diadakan diskusi kelas, (k) setelah semua kelompok selesai menampilkan hasil kerjanya dan diadakan diskusi kelas, guru menampilkan kembali hasil kerja salah satu kelompok yang dapat membantu siswa, yaitu yang menggambarkan hasilnya dalam bentuk diagram batang, untuk memahami pengertian rata-rata dari sekumpulan data, (1) guru mengadakan diskusi kelas untuk menggali pemahaman siswa tentang pengertian rata-rata dari sekumpulan data, (m) siswa diminta mendiskusikan dalam kelompoknya bagaimana cara mencari rata-rata dari hasil percobaan kacang hijau yang ditampilkan oleh guru untuk corong yang kecil, (n) dua atau tiga kelompok menyajikan hasil diskusinya dan diadakan diskusi kelas, (0) siswa membuat kesimpulan tentang bagaimana proses mencari rata-rata dari sekumpulan data percobaan, (p) siswa diminta untuk memaknai apa arti nilai rata-rata yang diperolehnya dengan pemahamannya tentang debit.

Adapun beberapa hasil penelitian yang mengatakan bahwa, peningkatan kemampuan pemecahan masalah matematik melalui pembelajaran Pendidikan matematika realistik lebih baik dibandingkan peningkatan kemampuan pemecahan masalah matematik melalui pembelajaran langsung (Anisa, 2014; Saefudin, 2012; Usdiyana, dkk, 2009; Ariyanti, 2016). Selain itu juga hasil penelitian yang mengatakan bahwa, peningkatan kemampuan komunikasi matematik melalui pembelajaran pendidikan matematika realistik lebih baik dibandingkan peningkatan kemampuan komunikasi matematik melalui pembelajaran langsung (Murdani, dkk, 2013; Zaini, 2014; Soviawati, 2011).

Dari pengalaman pada saat pengamatan seperti dijelaskan di atas, guru menyadari bahwa betapa pentingnya siswa diberikan kesempatan untuk membuat jalinan antara pengetahuan yang sudah dimiliki dengan pengetahuan baru yang akan dibangunnya. Menurut peneliti, hal ini dapat diakomodasi oleh pendekatan matematika realistik yang salah satu karakteristiknya adalah intertwining atau jalinan antar pengetahuan. Karena itu, peneliti bermaksud untuk mengadakan suatu penelitian yang dapat memunculkan karakteristik intertwining dalam proses pembelajaran yang dialami oleh siswa.

Rumusan masalah yang coba dijawab oleh peneliti melalui penelitian ini adalah sebagai berikut: (1) apa yang dimaksud dengan karakteristik intertwining atau jalinan antar pengetahuan di dalam pendekatan matematika realistik?,(2) apa yang perlu dilakukan oleh guru dalam proses pembelajaran matematika sedemikian hingga karakteristik intertwining dalam pendekatan matematika realistik dapat muncul?.

Penelitian ini bertujuan untuk mendeskripsikan: (1) karakteristik intertwining atau jalinan antar pengetahuan di dalam pendekatan matematika realistik, (2) apa yang perlu dilakukan guru dalam proses pembelajaran matematika hingga karakteristik intertwining dalam pendekatan matematika realistik dapat muncul.

\section{METODE}

Jenis penelitian yang dipergunakan dalam penelitian ini adalah penelitian pengembangan yang dikembangkan oleh Koeno Gravemeijer. Proses penelitian ini dibagi dalam tiga fase, yaitu persiapan uji coba desain, uji coba desain, dan analisis retrospektif. Pada fase pertama, peneliti menentukan tujuan pembelajaran dan membangun desain pembelajaran. Pada fase kedua, peneliti mengujicobakan desain pembelajaran dalam dua kali pertemuan. Pada fase ketiga, peneliti mengadakan analisis restrospektif terhadap hasilhasil yang dicapai oleh siswa dalam uji coba desain. Sesuai dengan rumusan masalah penelitian, maka pada analisis restrospektif yang dilakukan peneliti, peneliti menitikberatkan pada kemunculan karakteristik intertwining dalam uji coba desain yang dilakukan peneliti pada fase kedua dari penelitian ini. Proses pengumpulan data akan dilakukan dengan pengamatan dan perekaman video selama proses pembelajaran berlangsung. Subjek dalam penelitian ini adalah siswa kelas 6 di suatu SD swasta di Yogyakarta.

Menurut Gravemeijer \& Cobb (dalam Akker, et. al, 2006) ada 3 fase penelitian pengembangan, yaitu: pertama, persiapan uji coba desain. Menurut Gravemeijer \& Cobb (dalam Akker, et. al, 2006), persiapan untuk uji coba desain dimulai dengan mengklarifikasi tujuan-tujuan yang akan dicapai 
oleh siswa setelah mereka belajar matematika (endpoints). Setelah selesai menetapkan tujuan yang akan dicapai siswa, peneliti kemudian harus menentukan titik-titik awal pembelajaran (starting points). Sesudah tujuan yang akan dicapai siswa dan titik-titik awal pembelajaran selesai diformulasikan, maka tugas selanjutnya adalah memformulasikan dugaan teori pembelajaran lokal (aconjecturer local instruction theory) dari desain yang akan diujicobakan. Teori pembelajaran lokal berisi dugaan bagaimana proses pembelajaran akan terjadi, dugaan aktivitas pembelajaran yang produktif, budaya kelas yang diimpikan, dugaan bagaimana guru dapat berperan secara proaktif dalam pembelajaran, dan dugaan bagaimana siswa berpikir dalam proses pembelajaran tersebut.

Kedua, uji coba desain, menurut Gravemeijer \& Cobb (dalam Akker, et. al, 2006), tujuannya untuk meningkatkan dugaan teori pembelajaran lokal (a conjecture local instruction theory) yang sudah dikembangkan pada fase pertama, serta mengembangkan pemahaman bagaimana desain tersebut bekerja, dan kunci dari proses pengujian, peningkatan, dan pemahaman adalah proses siklik yang terintegrasi dari desain dan proses analisis. Juga ditegaskan bahwa, jantung dari penelitian pengembangan terletak pada proses siklik dari proses pembuatan/pembuatan ulang desain dan menguji aktivitas pembelajaran dan aspek-aspek lain yang ada dalam desain. Dalam setiap siklus, tim peneliti membuat suatu eksperimen dalam pikiran yang bersifat antisipatif (an anticipatory thought experiment) dengan membayangkan bagaimana aktivitas pembelajaran yang diusulkan dapat direalisasikan dalam interaksi di dalam kelas, dan apa yang siswa pelajari setelah berpartisipasi dalam aktivitas pembelajaran yang dirancang oleh peneliti. Selama pembuatan aktivitas pembelajaran di dalam kelas dan dalam peninjauan kembali, peneliti mencoba untuk menganalisis proses aktual partisipasi dan belajar siswa. Berdasarkan hasil analisis ini, peneliti membuat keputusan tentang kevalidan dugaan teori pembelajaran lokal yang diwujudkan dalam aktivitas pembelajaran, pembentukan norma-norma tertentu, dan revisi aspek-aspek tertentu dari desain. Uji coba desain terdiri atas proses-proses siklik dari eksperimen dalam pikiran (thought experiment) dan eksperimen pembelajaran (instruction experiment). Proses siklik dari eksperimen dalam pikiran (thought experiment) dan eksperimen pembelajaran (instruction experiment) digambarkan oleh Freudenthal (dalam Akker, Gravemeijer, McKeney, dan Nieveen, 2006) seperti tampak dalam gambar 1 .

Ketiga, analisis retrospektif, menurut Gravemeijer \& Cobb (dalam Akker, et. al, 2006), tujuan dari analisis retrospektif tergantung pada tujuan secara teori penelitian pengembangan dilakukan. Diantara tujuan utama analisis retrospektif adalah untuk mengembangkan teori pembelajaran lokal (local instruction theory). Meskipun adanya perbedaanperbedaan dalam tujuan secara teori dilakukannya penelitian pengembangan direfleksikan dalam perbedaan-perbedaan analisis retrospektif, tetapi bentuk analisis perlu meliputi suatu proses iteraktif yang menganalisis sekumpulan data yang masuk.

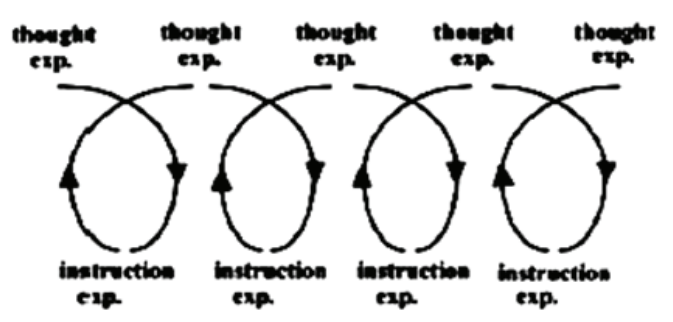

Gambar 1 Akumulasi Proses-Proses Siklik Penelitian Pengembangan

\section{HASIL DAN PEMBAHASAN}

Mace \& Ward, (2002) mengembangkan empat tahap-model proses berpikir kreatif siswa dalam penelitian mereka, yaitu: pertama, siswa mencoba untuk memahami konsep kreativitas; kedua, mengembangkan ide-ide dengan menata ulang ide-ide kreatif mereka, mengidentifikasi berbagai ide-ide mereka untuk mengembangkan mungkin karena perasaan mereka, kemudian mengevaluasi ide-ide dengan mempertanyakan dan melakukan metafora dan analogi; ketiga, mewujudkan ide-ide dengan mengubah ide menjadi sebuah entitas fisik; keempat, menyelesaikan dan melakukan resolusi kreativitas. Para siswa mengevaluasi produk kreatif mereka dengan memilih dan menentukan yang terbaik. Proses ini terjadi dalam konsep trial and error, yang berarti bahwa siswa akan mengubah dan menghancurkan produk yang salah dan mengekspos hasil yang memuaskan. Berdasarkan hasil pengembangan pembelajaran penjelasan untuk tiap fase yang dilakukan peneliti dalam penelitian ini adalah sebagai berikut. 
Fase 1: Menentukan tujuan pembelajaran, dan membangun desain pembelajaran. Siswa dapat membangun pengertian debit. Siswa dapat mengolah dan menyajikan data dalam bentuk tabel dan diagram. Siswa dapat membangun pengertian ratarata dari sekumpulan data hasil percobaan; Siswa dapat menghitung data-rata dari sekumpulan data hasil percobaan. Siswa dapat membangun jalinan pengetahuan antara konsep debit dan rata-rata.

Garis besar proses pembelajaran yang menggunakan pendekatan matematika realistik yang akan mencobakan desain pembelajaran adalah sebagai berikut.

Fase 2: Mengujicobakan desain pembelajaran. Desain pembelajaran yang dibangun oleh peneliti bersama dengan guru yang akan mencobakan desain tersebut diujicobakan pada tanggal 13 dan 20 Agustus 2009. Setelah proses pembelajaran berakhir, peneliti dan guru mengadakan refleksi tentang proses pembelajaran yang baru saja terjadi di kelas, dan menyempurnakan desain yang akan diujicobakan dalam pertemuan berikutnya berdasarkan hasil refleksi. Proses ini sejalan dengan berbagai temuan dalam penelitian yang berkaitan dengan pengaruh lingkungan sosial dan budaya kreativitas untuk diri sendiri, bahwa mengembangkan ide-ide kreatif selalu berhubungan dengan segala hal yang telah diterima seseorang dari lingkungan sosialnya dengan berinteraksi dengan orang lain (Sawyer, 2008; Stenberg \& Sternberg, 2012; Silvia \& Beaty, 2012). Peran guru disini adalah sebagai rangsangan lingkungan dalam hal interaksi sosial sehingga mampu menumbuhkan kreativitas murid.

Fase 3: Analisis retrospektif/hasil penelitian dan pembahasan. Berikut ini disajikan hasilhasil yang diperoleh dari uji coba yang dilakukan peneliti bersama guru yang menunjukkan proses kemunculan karakteristik intertwining dalam pendidikan matematika realistik.

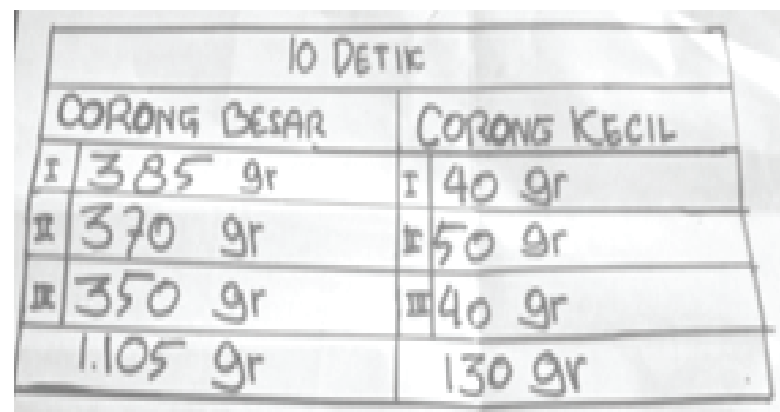

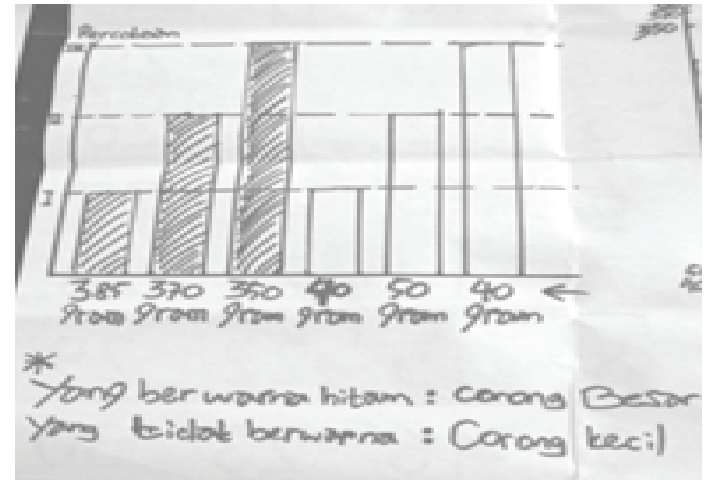

Gambar 2 Contoh Tabel dan Diagram Batang yang Dibuat oleh Salah Satu Kelompok

Dari diskusi kelas, siswa dapat menyimpulkan bahwa (1) debit dari kacang hijau yang mengalir melalui corong adalah banyak kacang hijau yang keluar melalui corong dalam satu satuan waktu, dan (2) debit kacang hijau yang mengalir melalui corong yang besar lebih besar daripada debit kacang hijau yang mengalir melalui corong yang kecil.

Siswa dapat menyajikan data hasil uji coba dengan kacang hijau dalam dua bentuk, yaitu tabel dan diagram batang. Contoh tabel dan diagram batang yang dibuat oleh siswa dapat dilihat pada gambar 2.

Interaksi yang dilakukan guru dan siswa dimana guru mencoba untuk memancing ide siswa tentang mencari rata-rata dari sekumpulan data yang sudah disajikan dalam diagram batang:

Guru: Kemarin si Anto cerita sama ibu, Bu, ini rata-ratanya begini bu.

Sekarang ada yang tahu gak ya, rata-rata percobaan yang pake corong kecil dapat berapa ya? Berapa?

Didit: 50 sampai 100 gram.

Guru: Rata-ratanya 50 sampai ...

Didit: 100 gram.

Guru: 100 gram kalau pakai corong kecil. Yang lain?

Yanto: Gak nyampe.

Dino: Nyampe.

Yanto: Gak nyampe.

Dari dialog di atas, siswa yang menjawab pertanyaan guru masih kesulitan membedakan konsep rata-rata dan perkiraan hasil suatu percobaan. Pada langkah berikut, guru mencoba untuk mengklarifikasi konsep rata-rata. Perhatikan dialog berikut: 
Guru: Bagaimana? Tadi ibu bilang kan tentang rata-rata ya. Kalau dalam Bahasa Indonesia itu rata-rata berasal dari kata? Dari? Itu kan pengulangan to, dari?

Benu: Rata.

Guru: Dari?

Benu: Rata.

Guru: Rata. Apa sih artinya rata itu?

Yanto: Sama. Sama rata.

Guru: Artinya rata apa? Artinya rata apa? Misalnya ini ibu punya kacang hijau (guru menunjukkan satu kota kacang hijau yang tingginya tidak sama. Apa yang ditunjukkan guru dapat dilihat pada gambar 3). Bisa tidak kalian meratakan kacang hijau ini? Coba ya?

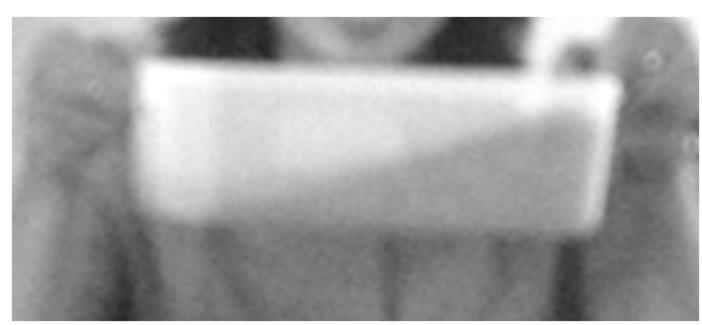

Gambar 3 Satu Kotak Kacang Hijau Dengan Tinggi yang Tidak Sama yang Ditunjukkan oleh Guru

Siswa: Heru bu. Her, Heru. Heru bu.

Guru: Oh Heru (siswa yang diminta oleh guru untuk meratakan tinggi kacang hijau dalam kotak yang telah ditunjukkannya maju ke depan kelas dan duduk pada kursi baris paling depan).

Bagaimana meratakannya Heru? (Heru mulai meratakan tinggi kacang hijau dengan cara menggeser kacang hijau yang lebih tinggi ke arah kacang hijau yang lebih pendek sampai tinggi semua kacang hijau sama).

Ya, terima kasih Heru. Bagaimana tinggi kacang hijau sekarang?

Siswa: Belum rata.
Guru: Belum rata? Kenapa?

Yanti : Karena masih ada lekuk-lekuknya.

Guru: Karena ini apa? Karena ini kacang. Ya.

Yanto: Kalau air bisa.

Guru: Ya, kalau air gampang ya bisa rata. Tapi kalau dibandingkan yang tadi?

Yanto: Rata ini.

Guru: Rata ini ya. Apa yang Heru lakukan?

Yanto: Meratakan.

Guru: Meratakan dari? Bagaimana dengan tingginya?

Yanto: Sama.

Guru: Sama. Tadi kan gini ya (guru mengembalikan keadaan kacang hijau sebelum diratakan oleh Heru).

Bagian di sini kenapa? (guru menunjuk bagian kacang hijau yang lebih tinggi).

Siswa: Lebih tinggi.

Guru: Bagian sini? (guru menunjuk bagian kacang hijau yang lebih rendah)

Siswa: Lebih rendah.

Guru: Yang dilakukan Heru tadi, pakai tangan ya tadi (guru mempraktekkan ulang cara Heru meratakan tinggi kacang hijau). Apa yang dilakukan sama Heru tadi?

Siswa: Meratakan.

Guru: Meratakan jadi?

Yanto: Rata.

Guru: Bagaimana dengan tingginya? Bagaimana dengan tingginya?

Siswa: Sama.

Guru: Tapi Heru mengurangi isinya ini tadi gak?

Siswa: Nggak.

Guru: Jadi bisa menjadi rata ya. Kita kembali ke sini, ke diagram batang yang sudah kalian buat (diagram batang yang dimaksud dapat dilihat pada gambar 4. Data yang digambarkan oleh siswa dalam gambar 4 dapat dilihat dalam tabel 1). Bagaimana dengan tingginya diagram ini? Bagaimana tingginya percobaan pertama, kedua, ketiga? Bagaimana?

Tabel 1 Hasil Percobaan Kacang Hijau yang Menggunakan Corong Besar dan Kecil untuk Waktu 10 Detik

\begin{tabular}{cccccc}
\hline \multicolumn{3}{c}{ Corong Besar (gram/10 detik) } & \multicolumn{3}{c|}{ Corong Kecil (gram/10 detik) } \\
\hline Percobaan 1 & Percobaan 2 & Percobaan 3 & Percobaan 1 & Percobaan 2 & Percobaan 3 \\
\hline 385 & 370 & 350 & 40 & 50 & 40 \\
\hline
\end{tabular}




\section{Yanto: Tidak rata.}

Guru: Belum rata. Bisa menjadi rata? Mau mencoba? (maksud guru adalah siswa diminta untuk mencari berapa rata-rata data hasil percobaan dengan corong kecil).

Siswa: Mau.

Guru: Baik, kalau begitu kalian coba dengan kelompoknya. Kita coba untuk corong yang kecil dulu ya.

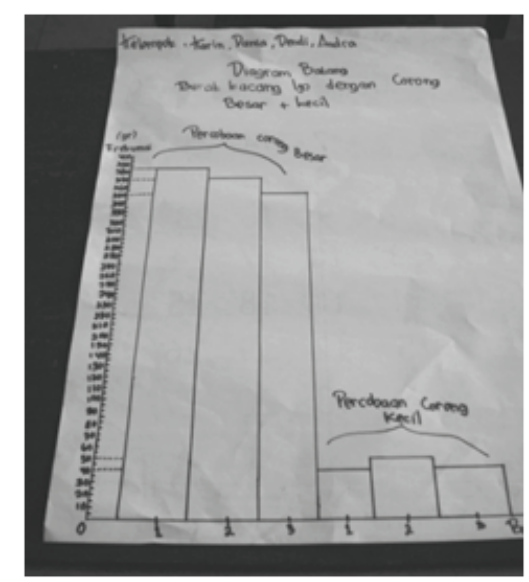

(a)

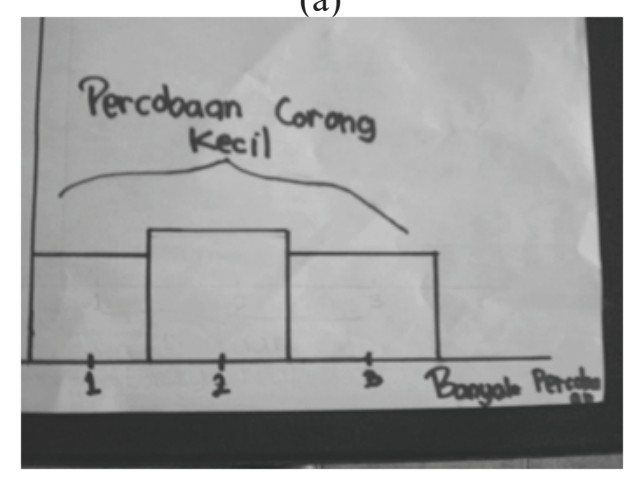

(b)

Gambar 4 (a) Gambar diagram untuk corong besar dan kecil yang dimaksud guru.

(b) Gambar diagram corong kecil yang rata-ratanya dicari siswa.

Model-model yang dibuat oleh siswa berdasarkan interaksi antara guru dan siswa; Model 1: siswa menggunakan diagram batang. Siswa menuliskan tinggi dari masing-masing diagram batang, yaitu 40 gram, 50 gram, dan 40 gram. Siswa melihat bahwa tinggi yang pertama dan ketiga sama, yaitu 40 gram. Tinggi yang berbeda dengan yang pertama dan ketiga hanya yang kedua, yaitu 50 gram. Siswa mencari selisih tinggi kedua dengan kedua tinggi yang lain, yaitu 10 gram. Siswa membagi 10 gram dengan 3. Pembagi tiga diperoleh siswa, karena dalam percobaan tersebut, dilakukan tiga kali percobaan. Hasil pembagian 10:3 diperoleh 3 sisa 1. Hasil pembagian, yaitu 3 ditambahkan dengan tinggi yang sudah sama, yaitu 40 gram, sehingga diperoleh 43 gram. Kemudian sisa 1 gram dibagi tiga lagi dan diperoleh hasil 0,33. Jadi, rataratanya diperoleh 43,33 gram.

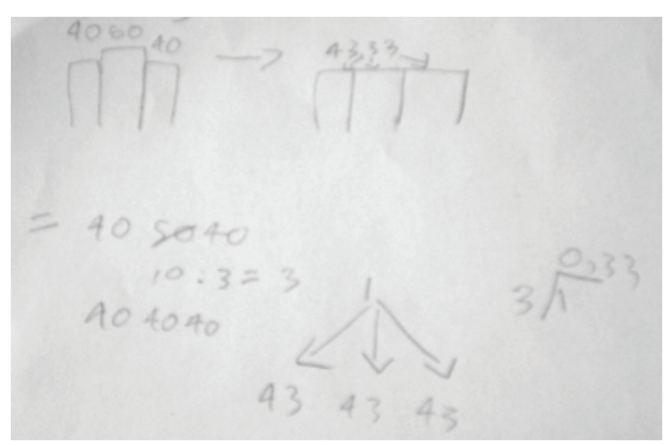

Gambar 5 model 1 dari masalah kacang hijau

Model 2: siswa menjumlahkan hasil percobaan pertama, kedua, dan ketiga, yaitu: 40 gram +50 gram +40 gram $=130$ gram. Siswa membagi hasil penjumlahan dengan 3 , bilangan 3 diperoleh dari banyak percobaan yang sudah dilakukan. Siswa memperoleh hasil pembagiannya 43,33 dengan cara "poro gapit". Siswa menyimpulkan rata-ratanya adalah 43,33 gram.
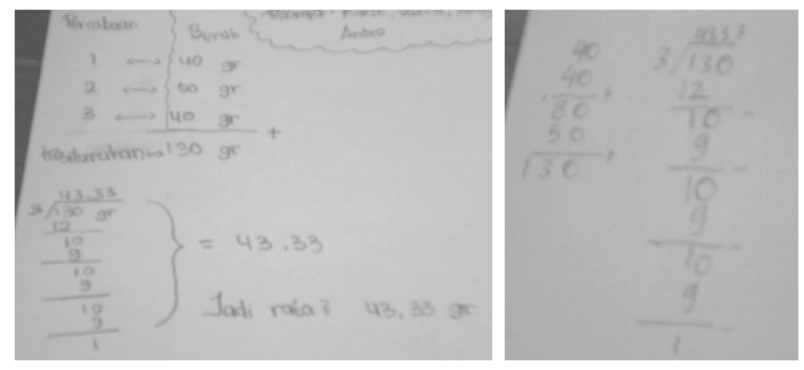

Gambar 6 Model 2 dari masalah kacang hijau

Interaktivitas antara guru dengan siswa ketika guru mendatangi satu kelompok yang sedang melakukan diskusi kelompok:

Guru: Seratus tiga puluh dari mana?

Andika: Ditambahkan semua bu.

Guru: Mana yang ditambah?

Andika: empat puluh ditambah empat puluh, kan delapan puluh, terus ditambah lima puluh, jadi seratus tiga puluh.

Guru: Jadi seratus tiga puluh.

Andika: Terus dibagi tiga. 
Guru: Dibagi tiga. Kenapa kok dibagi tiga.

Andika: Karena kan mau diratakan jadi tiga bu.

Guru: Diratakan jadi tiga. Dodi udah paham dengan cara Andika (Dodi adalah teman satu kelompok diskusi dengan Andika).

Dodi: Udah (sambil menganggukan kepala).

Guru: Coba tuliskan di sini (guru menunjuk pada selembar kertas kosong yang akan dipergunakan oleh siswa untuk menuliskan jawaban siswa tersebut).

Interaktivitas antara guru dengan siswa dan siswa dengan siswa ketika satu kelompok menyajikan hasil pekerjaannya di papan tulis. Guru meminta kelompok Yanto untuk menampilkan hasil diskusi kelompoknya. Kelompok Yanto terdiri atas dua orang, yaitu Yanto dan Budi. Budi menuliskan hasil diskusi kelompoknya di papan tulis. Ketika Budi menuliskan hasil diskusi kelompoknya, guru meminta siswa yang lain untuk mencermati, dan memahami apa yang dituliskan oleh Budi. Seselesainya Budi menuliskan hasil kerjanya, guru meminta siswa lain, yaitu Ridwan untuk menjelaskan apa yang dituliskan Budi di papan tulis (apa yang dituliskan Budi dapat dilihat pada gambar 7). Hal ini dilakukan oleh guru, supaya siswa mau menyimak dan memahami apa yang diungkapkan oleh temannya yang sedang menyajikan hasil pekerjaannya dan membandingkan dengan apa yang sudah dikerjakannya. Hal ini merupakan bagian dari proses negosiasi.

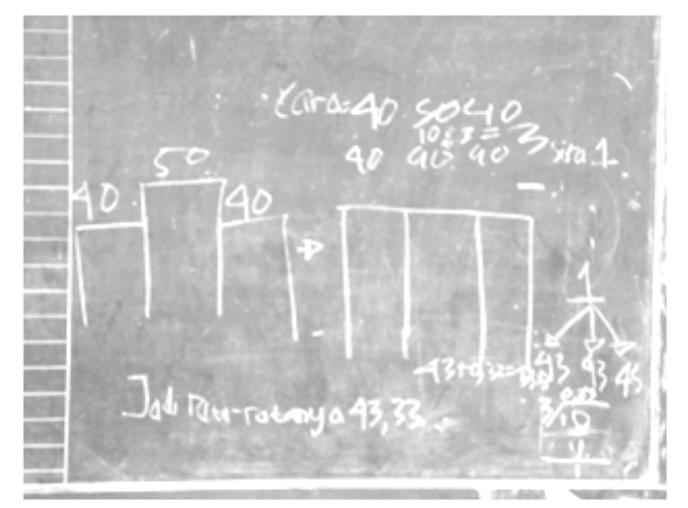

Gambar 7 Hasil diskusi Yanto dan Budi yang Dituliskan di Papan Tulis

Ridwan: Ini kan 40, 50, 40 (siswa menunjuk bilangan-bilangan yang menyatakan tinggi dari diagram batang), yang 50 ini dikurangi 10. Baru yang sepuluh diambil sembilan, jadinya dibagi tiga sisanya satu (siswa menunjuk bilangan 50 yang dicoret, kemudian ada tulisan di bawahnya $10: 3=3$ sisa 1). Ini sisa satu kan, baru yang satunya ini dibagi tiga, jadi hasilnya nol koma tiga tiga. Jadi digabung hasilnya menjadi empat puluh tiga koma tiga tiga.

Guru: Begitu caranya?

Yanto dan Budi: (kedua siswa tidak menjawab hanya menganggukan kepala).

Guru: Wah pinter. Padahal melihat tulisan Budi ibu bingung, tetapi Ridwan bisa membacanya ya.

Ridwan: Soalnya caranya sama.

Guru: O, caranya sama. Yo, Wati ada yang mau ditanyakan nggak.

Wati: (siswa tersebut diam saja dan hanya tersenyum).

Guru: Mau tanya apa?

Wati: (siswa tersebut diam saja dan hanya tersenyum).

Guru: Hayo Wati, ada nggak. Ok, bagaimana dengan caranya Yanto ini membuat rata ini, Setuju nggak kalian dengan caranya Yanto ini.Ini sudah rata belum ini? Kira-kira. Udah rata belum? Heru, udah rata belum Heru?

Heru: (siswa tidak menjawab pertanyaan guru, hanya tersenyum, dan siswa tampak masih bingung dengan cara yang disajikan oleh kelompok Yanto di depan kelas).

Guru: Ha, belum tahu?

Heru: Sudah bu.

Guru: Untuk cara Yanto dan Budi, yang sudah paham angkat tangannya. Ridwan to, Beni, Siska, Andika, Aldi. Siapa yang belum paham (Heru mengangkat tangan, kemudian disusul Wati, Dino, dan Susi mengangkat tangan). Ternyata ada juga yang belum paham. Yuk, mungkin Budi bisa jelaskan atau mungkin Yanto silahkan.

Yanto: Maksudnya kan, tadi lho, tadi grafik batangnya yang corong kecil kan yang pertama 40, yang 
kedua 50, ketiga 40. Apa, ibunya kan minta tolong supaya menghitung rata-rata semuanya berapa. Trus, habis itu, ini dibuat rata (siswa menunjuk gambar grafik batang yang tingginya sama, yaitu 40). Sini 40, sini 50, sini 40. Trus sini 50 dikurangi 40, yang sisanya 10 ini (maksud siswa adalah hasil pengurangan 50 dengan 40) dibagikan untuk ketiga ini (siswa menunjuk batang yang masing-masing tingginya 40). Trus sepuluh dibagi tiga sama dengan tiga sisa satu. Tiganya ini dikasihkan ini, ini, sama ini (siswa menunjuk batang yang masing-masing tingginya 40), jadinya hasilnya 43 (yang dimaksud siswa adalah masing-masing tinggi batang, yaitu 40 ditambah dengan 3, sehingga diperoleh tinggi pada sekarang adalah 43). Habis itu, satunya ini (satu adalah sisa pembagian sepuluh dengan tiga) dibagi dengan tiga. Hasilnya nol koma tiga tiga. Trus ditambahkan, empat puluh tiga ditambah nol koma tiga tiga sama dengan empat tiga koma tiga tiga.

Guru: Bagaimana Susi? Udah ngerti?

Susi: (siswa tidak menjawab dan hanya menganggukan kepala).

Dari aktivitas yang dilakukan guru di atas, tampak bahwa pada awalnya guru mencoba menghubungkan antara percobaan yang dipergunakan untuk mengenalkan konsep debit dengan konsep diagram dalam statistika. Hal ini sesuai dengan pendapat Tanziah, et al. (2013:120) yang menyatakan bahwa pembelajaran matematika lebih bermakna ketika terkait dengan pembelajaran sebelumnya. Hal ini dapat dilakukan oleh guru, karena dari percobaan dengan kacang hijau, siswa mendapatkan data yang dapat disajikan dalam bentuk diagram yang bermakna bagi siswa. Guru tidak mengajari bagaimana siswa harus membuat diagram, tetapi siswa sudah dapat menyajikan hasil percobaan dengan kacang hijau dalam bentuk diagram, di mana salah satu bentuk yang dibuat oleh siswa adalah diagram batang. Hal ini sejalan dengan pendapat Widyastuti \& Pujiastuti (2014:184) yang menyatakan bahwa pengetahuan dan kemampuan bukan merupakan hasil transfer ilmu dari guru ke siswa, akan tetapi pengetahuan dan kemampuan dibentuk sendiri oleh siswa melalui pengalaman nyata dengan mengaitkan pengetahuan yang telah dimilikinya. Dalam hal ini, guru sangat pandai dalam memanfaatkan hasil yang sudah diperoleh siswa, yaitu penyajian data dalam bentuk diagram batang untuk mengenalkan konsep rata-rata. Guru secara baik dapat mengilustrasikan apa arti kata rata-rata dengan menggunakan kata "rata", ilustrasi kacang hijau, dan diagram batang yang sudah dihasilkan oleh siswa, sehingga siswa dapat memahami konsep rata-rata. Dengan kata lain, dalam aktivitas yang dilakukan oleh guru tersebut, guru mencoba membuat hubungan (intertwining) antara konsep debit, diagram, dan rata-rata dalam matematika.

\section{SIMPULAN DAN SARAN}

\section{Simpulan}

Karakteristik intertwining dalam pendekatan matematika realistik menekanan bahwa rangkaian pembelajaran tidak dapat diperlakukan sebagai sesuatu yang sungguh-sungguh terpisah, sebaliknya, suatu jalinan dari rangkaian pembelajaran harus dimanfaatkan dalam penyelesaian masalah. Halhal yang perlu dilakukan guru agar siswa dapat membentuk jalinan dari rangkaian pembelajaran adalah sebagai berikut ini.

Pertama, guru membuat rangkaian masalahmasalah atau fenomena-fenomena yang dapat dieksplorasi dan diselesaikan oleh siswa sedemikian hingga siswa secara bertahap dapat sampai pada pengetahuan formal matematika yang diinginkan untuk dicapai oleh siswa. Agar masalah atau fenomena tersebut dapat dieksplorasi dan diselesaikan oleh siswa, guru perlu (a) mengetahui pengetahuan yang sudah dimiliki oleh siswa, (b) memberikan kesempatan kepada siswa untuk menyelesaikan masalah tersebut dengan cara yang dipahaminya, (c) memberikan bantuan, dapat menggunakan alat peraga, maupun dengan pertanyaan, seperti yang terjadi pada proses pembelajaran di atas, sedemikian hingga siswa dapat mengembangkan pengetahuan yang dimilikinya untuk menyelesaikan masalah tersebut, dan (d) mengetahui berbagai lintasan belajar yang 
dapat dibuat oleh siswa melalui rangkaian masalah atau fenomena yang diberikan oleh guru. Kedua, guru mengembangkan pola interaksi dua arah baik dalam interaksi antara guru dengan siswa maupun antar siswa.

\section{Saran}

Karakteristik intertwining memiliki peranan penting, yaitu (1) membuat pengetahuan yang dibentuk siswa tidak terkotak-kotak, (2) menjadikan pola pikir siswa tidak bersifat mekanistik, (3) membuat siswa tidak mengalami ketergantungan pada ingatan terhadap prosedur atau pun rumus untuk menyelesaikan suatu masalah, dan (4) meningkatkan kreativitas siswa. Guru dalam menyampaikan materi dalam pembelajaran matematika perlu menggunakan pendekatan ini sehingga murid lebih dapat mengonstruk pengetahuan dengan baik.

\section{DAFTAR RUJUKAN}

Akker, Jan Van Den, Gravemeijer K., McKenney S., dan Nieveen N. 2006. Educational Design Research. New York: Taylor and Francis Group. Anisa, W.N. 2014. Peningkatan Kemampuan Pemecahan Masalah dan Komunikasi Matematik Melalui Pembelajaran Pendidikan Matematika Realistik untuk Siswa SMP Negeri di Kabupaten Garut. Jurnal Pendidikan dan Keguruan. 1 (1):77-89

Ariyanti, H.P. 2016. Pengaruh Pembelajaran Matematika Realistik terhadap Kemampuan Matematis Siswa (Ditinjau dari Kemampuan Representasi dan Komunikasi). Jurnal Buana Matematika. 6 (2):25-30

Gravemeijer, K. P. E. 1994. Developing Realistic Mathematics Education. Utrecht: Freudenthal Institute.

In'am, A. 2012. Perspektif Metakognitif Guru dalam Pembelajaran Matematika di Sekolah Dasar. Jurnal Sekolah Dasar; Kajian Teori dan Praktik Pendidikan, 21(2):133-144.

Julie, H., Suwarsono, St., dan Juniati, D. 2013. The First Cycle of Developing Teaching Materials for Fractions in Grade Five Using Realistic Mathematics Education. IndoMS Journal on Mathematics Education, 4(2):172-87.
Mace, M., \& Ward, T. 2002. Modeling the creative process: A grounded theory analysis of creativity in the domain of art making. Creativity Research Journal, 14, 179-192.

Murdani, Johar, R., \& Turmudi. 2013.Pengembangan Perangkat Pembelajaran Matematika dengan Pendekatan Realistik untuk Meningkatkan Penalaran Geometri Spasial Siswa di SMP Negeri Arun Lhokseumawe. Jurnal Peluang. 1 (2), 22-32

Sawyer, R. 2008. Optimising Learning: Implications of Learning Sciences Research. OECD/CERI International Conference, 4(1):78-89.

Saefudin, A.A. Pengembangan Kemampuan Berpikir Kreatif Siswa dalam Pembelajaran Matematika dengan Pendekatan Pendidikan Matematika Realistik Indonesia (PMRI). Al-Bidayah. 4 (1),37-48

Silvia, P. J., \& Beaty, R. E. 2012. Making Creative Metaphors: The Importance Of Fluid Intelligence For Creative Thought. Intelligence, 40(4):343351.

Soviawati, E. 2011. Pendekatan Matematika Realistik (PMR) untuk Meningkatkan Kemampuan Berfikir Siswa di Tingkat Sekolah Dasar. Jurnal Khusus. 2, 79-85

Sternberg, R. J., \& Sternberg, K. 2012. Cognitive Psychology. Pomona: California State University.

Tanzimah, Somakim, \& Santoso, B. 2013. Desain Pembelajaran Operasi Penjumlahan dan Pengurangan Bilangan Bulat Menggunakan Media Permainan Kakisambe di Kelas IV Sekolah Dasar. Jurnal Sekolah Dasar, 22(2):112-121.

Usdiyana, D., Purniati, T., Yulianti, K., \& Harningsih, E. 2009. Meningkatkan Kemampuan Berpikir Logis Siswa SMP Melalui Pembelajaran Matematika Realistik. Jurnal Pengajaran MIPA. 13(1):1-14

Widjaja, W., Fauzan, A., and Dolk, M. 2010. The role of contexts and teacher's questioning to enhance students' thinking. Journal of Science and Mathematics Education in Southeast Asia, 33(2):168-186.

Widjaja W., Julie H. Prasetyo A. B. 2009. Potret dan Kajian Proses Pembelajaran Matematika di Beberapa SD PMRI. Laporan Penelitian Hibah Strategi Nasional DIKTI 2009 No. 378/ SP2H/PP/DP2M/VI/2009. 
Widjaja, W. 2013. The use of contextual problems to support mathematical learning. IndoMS Journal on Mathematics Education, 4(2):151 - 159.

Widyastuti, N.S. \& Pujiastuti, P. 2014. Pengaruh Pendidikan Matematika Realistik Indonesia (PMRI) terhadap Pemahaman Konsep dan Berpikir Logis Siswa. Jurnal Prima Edukasia, 2(2):183-193.

Zaini, A. 2014. Perbandingan Keefektifan Pembelajaran Matematika dengan Pendekatan Matematika Realistik dan Konvensional Ditinjau dari Kemampuan Komunikasi Matematik Siswa. JPM IAIN Antasari. 2(1):1-20 